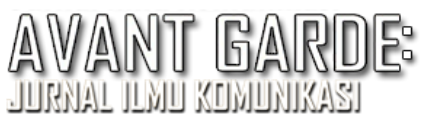

- ISSN: 2333-13308

$3-155 N=235 \%-151 \%$

\title{
Komunikasi Dosen dengan Mahasiswa Kelompok Digital-natives di Perguruan Tinggi
}

\author{
Indra Novianto Adibayu Pamungkas \\ Indrapamungkas@telkomuniversity.ac.id \\ Universitas Telkom, Jl. Telekomunikasi No. 01, Terusan Buah Batu, Sukapura, Dayeuhkolot, Bandung, \\ Jawa Barat 40257
}

Submitted: 25 Maret 2021, Revised: 18 April 2021, Accepted : 21 April 2021

\begin{abstract}
Abstrak
Komunikasi perlu dibangun antara dosen dan mahasiswa dalam proses pembelajaran di perguruan tinggi. Adanya kesenjangan generasi yang terjadi antara dosen dan mahasiswa pada proses pembelajaran. Dosen menghadapi peserta didik dengan konsep berpikir yang berbeda. Konsep pemikiran mahasiswa dipengaruhi oleh adopsi teknologi sejak mereka masih kecil dan kelompok mahasiwa ini dikenal dengan istilahdigital-native. Kondisiini menghadirkan kesenjagan antara dosen dan mahasiswa. Penelitian ini bertujuan untuk memberikan informasi terkait identitas personaldigital-nativessebagai dasar untuk melakukan komunikasi dalam pembelajaran. Pencarian data dalam penelitian ini menggunakan pendekatan tinjauan kepustakaan. Peneliti memperhatikan teks pada setiap rekam jejak mulai penggunaan istilahdigital-nativesmenjadi terminology pada tahun 2001 hingga perkembangannya di tahun 2020. Peneliti menghadirkan teori identitas karena indentitas dianggap sebagai produk komunikasi. Hasil penelitian menunjukkan bahwa generasidigital-nativesmemiliki pemikiran yang berbeda akibat terpaan teknologi dalam perkembangan hidupnya. D isisi lain, perlunya mengkaji kelompok generasi sesuai dengan kondisi latar belakang geografi atau daerah yang pada kenyataannya memiliki terpaan teknologi yang berbeda-beda. Perlunya kesadaran pengajar bahwa ada identitas baru yang kini hadir di dunia pendidikan perguruan tinggi. Mengenal generasidigital-natives akan membantu dosen untuk mengetahui cara berkomunikasi dengan generasi ini sebagai mahasiswa mereka.
\end{abstract}

Kata kunci : digital-natives, identitas, komunikasi pembelajaran, dosen, mahasiswa

\section{Lecturer Communication with the Digital-natives Students In Higher Educations}

\begin{abstract}
Lecturers and students need to build communication for the learning process in higher education. There is a generation gap that occurs between lecturers and students in the communications process. There is a presence of different ways of thinking concepts from the university students. Their way of thinking has been influenced by technological adoption since they were kids. This Generation is known as the digital-natives group. This study aims to provide information related to personal digital-natives identity as a basis for communicating in learning. This investigation uses a literature review as data determination. Researchers pay attention to the text in each track record, starting from the use of the term digital-natives into terminology in 2001 until its development in 2020. The researcher presents a theory of identity because identity is considered a communication product. The results showed that the digital-natives generation has different thoughts due to exposure to technology in the development of their lives. On the other hand, it is necessary to study generation groups according to geographic or regional background conditions which have different technological exposure. The need for the awareness of teachers that there is a new identity that is now present in the world of tertiary education. Getting to know the digital-natives generation will help lecturers to know how to communicate with this generation as their students.
\end{abstract}

Keywords : digital-natives, identity, communication education, lecturer, students 


\section{PENDAHULUAN}

Perkembangan teknologi dan informasi menghadirkan generasi baru dengan pola pemikiran pemikiran yang menyertainya. Generasi ini bertumbuh kembang bersama dengan teknologi yang diadopsinya sejak mereka kecil. Generasi ini mengenal teknologi seperti penggunaan internet, ipad dan komputer sejak dini. Teknologi digital- menghadirkan bayibayi yang lahir dan tumbuh bersamaan dengan teknologi. March Prensky (2001) melalui memperkenalkannya dengan terminologi “digital-native"(Prensky, 2001a). Generasi ini hadir di perguruan tinggi sebagai mahasiswa. Kapasitas kognitif pada tingkat perguruan tinggi tentunya tidak bisa lepas dari hadirnya suatu generasi yang berperan pada masanya. Setiap revolusi industri juga melahirkan dan menghadirkan generasi-generasi dengan identitas yang terbentuk pada jamannya.

Kehadiran generasi digital-natives menimbulkan kesenjangan dalam dunia pendidikan. Bahkan Prensky (2001) menjelaskan bahwa konsep pendidikan yang disususun oleh generasi sebelumnya sudah tidak cocok lagi digunakan di era ini. Ia menjelaskan bahwa pengajar datang dari generasi digital-mmigranty ang mempelajari cara belajar dari kelompok digital-mmigrant sebelumnya. Generasi yang teradopsi teknologi digital-mengalami keanehan dengan kapur dan papan tulis. Mereka terbiasa belajar dengan visual karena sejak kecil mereka keakraban mereka dengan teknologi. Perlunya memahami generasi yang hadir bersamaan dengan revolusi industri seperti yang terdapat dalam (tabel 1.1) berikut ini:

Tabel 1. Generasi dan Revolusi Industri

\begin{tabular}{|l|l|l|}
\hline No & Generasi & Tahun Lahir \\
\hline 1 & Radio Babies atau Silent Generation & $1930-1945$ \\
\hline 2. & Baby Boomers & $1946-1964$ \\
\hline 3 & Generation Xers (Generation Busters) & $1965-1976$ \\
\hline 4 & Generation Ys (generation Why) & $1977-1990$ \\
\hline 5 & Millennial & 1990 ataulebih \\
\hline
\end{tabular}

Sumber :(Gravett, Linda; Trockmorton, 2007)

Peneliti melihat pada tabel di atas dan dikondisikan dengan realitas pendidikan di Indonesia. Profesi dosen rata-rata berada pada generasi Baby Boomers hingga millennial generasi awal.Jurnal behaviour and information technology memberikan keterangan bahwa perbedaan antara kategori generasi penting untuk dieksplorasi terutama terkait pengalaman hidup termasuk perilaku, sikap pribadi dan profesional (Metallo \& Agrifoglio, 2015). Pengalaman hidup akan membantuk pemikiran yang menjadi identitas bagi suatu generasi. Hubungan antara identitas dan komunikasi menjadi perhatian banyak peneliti. Bila dikaitkan dengan lingkungan pendidikan, dosen tidak dapat menunjukkan identitasnya hanya untuk dirinya sendiri. Identitas dosen akan menjadi perilaku sosial ketika berinteraksi dengan mahasiswa. Identitas tidak dapat dipisahkan dari kegiatan komunikasi karena ia merupakan produk komunikasi (Jung \& Hecht, 2004; McCune, 2019).

Pada tabel 1.1 menunjukkan adanya rentang tahun kelahiran yang menunjukkan adanya perbedaan usia. Peneliti menyebarkan kuisioner pada mahasiswa generasi digitalterkait kendala usia dalam membina komunikasi dengan dosen. Kusioner ini disebarkan melalui Google form dan peneliti mendapatkan tanggapan dari 40 (empat puluh) mahasiswa. Mahasiswa yang memberikan tanggapan berasal dari Bandung, Medan, Bekasi, Surabaya dan Jakarta dan mendapati hasil sebagai berikut : 


\section{Apakah anda merasa faktor usia antara anda dengan dosen anda menjadi kendala komunikasi \\ 40 tanggapan}

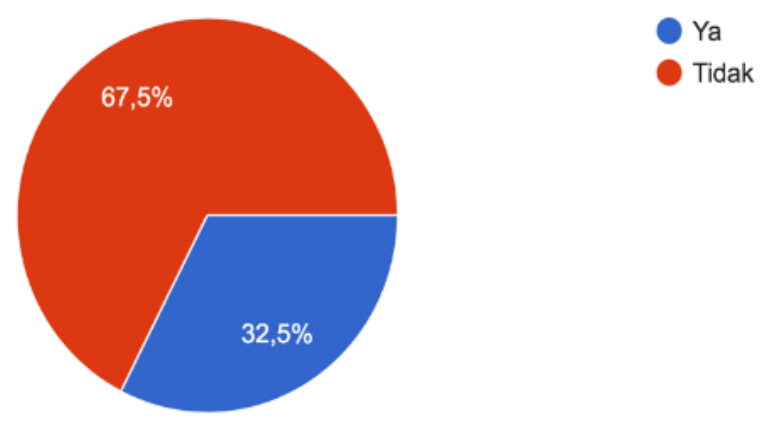

\section{Diagram I. Survey Usia dan Komunikasi}

Diagram 1 menunjukkan 67,5\% mahasiswa tidak menganggap usia menjadi kendala berkomunikasi dengan dosen mereka. Faktor usia tidak menjadi alasan utama untuk membina hubungan melalui komunikasi dengan dosen bagi sebagian besar responden. Peneliti melihat kondisi ini berhubungan dengan bagaimana seorang dosen dapat memproses informasi dan komunikasi dengan mahasiswa. Peran identitas dosen tercermin dari perkenannya untuk melakukan negosiasi identitas pada dirinya sendiri (Ennerberg \& Economou, 2020). Bila seorang dosen mampu bernegosiasi dengan dirinya sendiri akan menunjukkan konsep berpikir dalam membina hubungan dengan mahasiswa mereka. Konsep berpikir berkenaan dengan identitas yang akan direalitaskan melalui konsntruksi sosial melalui cara berkomunikasinya.

Kemampuan cara berkomunikasi menyesuaikan dengan realitas sosial kehidupan seorang dosen. Proses pembelajaran di era digital- membuat dosen tidak bisa menghindari hadirnya teknologi dan informasi digital-. Perlunya dosen bernegosiasi dengan keadaan internet yang semakin menunjukkan maturity nya. Pada kenyataanya, dosen sedang menghadapi mahasiswa yang sudah terbiasa dengan kehidupan digital- yang secara tidak langsung membentuk identitasnya secara berkomunikasi. Kondisi ini menghadirkan kesenjangan yang tidak bisa dihindari antara dosen dan mahasiswa. Sebuah penelitian menunjukkan bahwa kesenjangan digital- dapat dilihat dari berbagai aspek termasuk keterampilan dan perbedaan penggunaan internet antara dosen dan mahasiswa dalam lingkungan pendidikan (Hargittai, 2002, van Dijk, 2005 dalam Correa, 2015).

Realitas lingkungan perguruan tinggi menunjukkan bahwa dosen saat ini mengajar di tengah perubahan era. Kemampuan dosen mengajar di era digital- dan menghadapi identitas mahasiwa baru ini akan membentuk konstruksi sosial. Idengitas seorang dosen akan tercermin ketika sedang berkomuniksi dengan mahasiswa dalam proses belajar mengajar atau kehidupan sehari-hari. Penyesuaian cara berkomunikasi diperlukan bagi dosen dari kelompok digital- immigrant yang memiliki cara yang berbeda dalam menyerap informasi dan 
berkomunikasi. Generasi ini membutuhkan kemauan melakukan negosiasi mulai dari dirinya untuk mengadopsi teknologi dan informasi. Generasi ini mempelajari proses pendidikan dari generasi digital-immigrant sebelumnya(Prensky, 2001a) yang tidak terterpa teknologi digital sepenuhnya.

Dosen dari generasi digital-immigrant mengalami tuntutan dari sisi perubahan kondisi pendidikan secara teknologi dan mengharuskan berkomunikasi dengan generasi yang berbeda dari sebelumnya. Dosen kelompok ini dituntut untuk mempelajari multiplatform untuk menyesuaikan dengan kondisi pendidikan yang bisa diterima oleh generasi terkini. Mahasiwa yang dihadapi memilki cara belajar yang berbeda dan tidak sama dalam penerimaan materi pembelajaran. Jika sebelumnya keterlibatan teknologi tidak terlalu besar maka kini dosen harus menghadapi mahasiswa yang mencari informasi dengan bebas melalui jaringan internet. Kondisi ini membuat sumber yang didapat oleh mahasiswa tidak sesuai dengan kaidah akademik maka dosen perlu menjadi fasilitator. Dosen perlu memahami perubahan kondisi ini dengan menyesuaikan cara penyampaian dalam kegiatan belajar mengajar(Uygarer, Uzunboylu, \& Ozdamli, 2016).

Perubahan cara belajar mahasiswa dari generasi digital-natives ini menjadi perhatian dunia. Penelitian-penelitian hadir dari berbagai macam sudut pandang. Penelitian dari sudut pandang edukator juga pernah dibahas dalam jurnal internasional dan fokus pada pendidikan pada digital-natives dalam kurikulum akuntansi (Al-Htaybat, von Alberti-Alhtaybat, \& Alhatabat, 2018) hingga perangkat yang digunakan ketika hendak mengajar kelompok digital-natives yang memiliki dampak dalam interpersonal dalam kehidupan sehari-hari, pembentukan identitas, dan kegiatan sosial lainnya (Warf, 2018). Perhatian dari peneliti pendidikan menunjukkan pentingnya menyesuaikan identitas dengan hadirnya kelompok generasi ini dalam dunia pendidikan.

Pengenalan kehadiran kelompok digital-natives ini dapat menjadi bekal bagi dosen ketika melakukan interaksi dengan mahasiswanya. Setiap universitas akan menerima mahasiswanya dari berbagai macam latar belakang mengingat Indonesia adalah negara kepulauan dengan beragam identitasnya. Beragam latar berlakang secara geodemografi akan menunjukkan perbedaan adopsi teknologi. Keberagaman mahasiswa akan melebur ketika mereka berada dalam satu lingkungan yang sama yaitu Universitas. Mereka akan berbagai identitas melalui proses komunikasi dan mempengaruhi satu sama lain. Kondisi ini seolah membentuk kesetaraan dalam berbagai bidang seperti pengetahuan, standar gaya hidup, cara berkomunikasi dan pergaulan.

Kesertaraan itu akan terlihat dalam proses belajar mengajar meskipun masing-masing mahasiswa membawa identitas personal yang berbeda-beda. Identitas dapat terliat ketika masing-masing individu berbagi makna melalui komunikasi. Perlunya mencermati lebih dalam terkait identitas bagi dosen dan mahasiswa generasi digital dari sisi keilmuan komunikasi. Kondisi identitas sebagai produk komunikasi ditunjukkan dengan hadirnya teori Identitas komunikasi dari Michael Hect pada tahun 2004. Teori ini melihat identitas dari empat lapisan (layer) yang menyertainya yaitu personal identity, enacted identity, relational identity dan communal identity (Brooks \& Pitts, 2016; Jung \& Hecht, 2004). 


\section{METODE PENELITIAN}

Penelitian ini merupakan kajian pustaka melalui penelaahan pada buku-buku dan jurnal terdahulu. Peneliti menginterpretasikan hasil temuan pustaka dalam penelitian ini untuk melihat perkembangan komunikasi pendidikan dengan hadirnya generasidigitalnatives. Peneliti menggunakan Communication Theory of Identity (CTI) untuk membingkai penelitian ini. Pemahaman terkait digital-natives akan dibentuk melalui layer-layer CTI yaitu personal, enactment, relational dan communal(Bergquist, Soliz, Everhart, Braithwaite, \& Kreimer, 2019)

\section{HASIL DAN PEMBAHASAN}

\section{Identitas Personal Generasi Digital-Natives dan Perkembangannya}

Terminologi digital-natives diperkenalkan oleh seorang pendidik, penulis buku dan konsultan bernama Marc Prensky pada tahun 2001. Ia menulis artikel yang berjudul digitalnatives, digital-immigrant yang terbagi dalam dua artikel. Prenksy (2001) mengatakan bahwa dunia sedang mengalami masalah kesenjangan antara murid dari kelompok digital-natives dengan pengajar mereka. Kelompok pengajar didominasi oleh pemikiran kelompok digitalimmigrant (Memoriautopis.com, 2020). Prensky (2001) mengawali tulisannya dengan pertanyaan "What should we call these "new" students of today?". Prensky memberikan label pada generasi ini sebagai digital-natives, net generation, google generation atau millennials. Label ini merupakan penggambaran anak muda yang sedang sekolah dan universitas di era digital (Helsper \&; Eynon, 2010; Prensky, 2001).

Prenksy menggunakan istilah digital-natives karena adopsi teknologi membuat generasi ini dengan perangkat digital. Generasi ini juga disebut sebagai native-speaker in digital era. Istilah native-speaker menunjukkan bahwa generasi ini familiar dengan bahasa yang ada di video game, komputer dan Internet karena mereka sudah teradopsi sejak mereka lahir. Pesonaliti dari generasi ini terlihat sebagai kelompok yang terbiasa menerima informasi dengan sangat cepat. Kelompok ini akan cepat memahami pembelajaran melalui infografis dibandingkan dengan teks. Kelompok ini merupakan generasi yang kritis terhadap penggunaan metode. Penggunaan metode bagi kelompok ini bukan hanya terbatas terhadap masalah "penggunaan" saja tapi "bagaimana penggunaan itu akan berlaku di masa depan". Bila diaplikasikan pada proses pembelajaran matematika, kelompok ini akan tidak hanya menggunakan kalkulator secara proses tapi mereka melihat bagaimana perkembangan kalkulator di masa depan (Prensky, 2001).

Peneliti mencermati identitas personal dari generasi digital yang berbeda dari generasi sebelumnya yang menerima ilmu untuk penggunaan. Identitas personal generasi digital terbentuk dengan nilai-nilai yang mereka dapatan melalui kehadiran teknologi. Kehadiran teknologi diperkenalkan oleh orang tua mereka sejak kecil agar mereka tenang menjalani aktivitas. Pengenalan ini dimulai dari pemberian gadget seperti I-Pad sehingga mereka terbiasa dengan audio-visual sejak dini. Kondisi ini dibawa pada tingkatan enactment sebagai pembelakuan identitas personal mereka melalui aktivitas mereka di dunia pendidikan.

Kondisi ini juga terlihat ketika generasi ini memberlakukan identitasnya (enactment) di mana kebiasaan yang muncul sejak dini dibawa sampai mereka memasuki perguruan 
tinggi. Kondisi ini menjadikan self-concept yang diberlakukan ketika mereka berada di lingkungan umum seperti sekolah dan kampus. Kondisi ini dapat menjadi acuan mereka dalam menerima informasi khususnya ketika proses komunikasi berjalan dalam konteks komunikasi pendidikan khususnya dalam penyampaian materi. Pada dasarnya identitas mahasiswa digital-natives tinggi tidak hanya mendefinisikan seseorang mahasiswa sebagai individu namun mencerminkan peran sosial sekaligus hubungan melalui komunikasi (Ramsey, Knight, \&; Knight, 2019). Identitas pribadi menunjukkan konsep diri mahasiswa digital-natives atau definisi diri mahasiswa digital-natives. Hasil telaah pustaka menunjukkan bahwa standar yang berlaku dalam pembahasan terkait digital-natives masih berkiblat pada pemikiran barat sehingga pantas saja jika penggunaan standar terkait digitalnatives pada setiap negara akan berbeda-beda (Gheorghiu \&; Stephens, 2016; Hecht, 1984, 1998; Jaspal, 2015; McCune, 2019; Ramsey et al., 2019).

Perkembangan penelitian penggunaan Istilah digital-natives menuai kritikan dan sempat diperdebatkan. Berdasarkan hasil telaah pustaka peneliti menemukan bahwa tujuh tahun kemudian (2008), Sue Bennett seorang senior lecturer dari Fakultas Pendidikan Univerisitas Wollongong, Karl Maton, seorang dosen dari jurusan sosial dan kebjakan sosial Universitas Sydney dan Lisa Kervin seorang dosen di fakultas pendidikan University of Wollongong menulis tentang The 'digital-natives debate: A critical review of the evidence melalui British Jurnal of Educational Technology. Kondisi ini seolah-olah menyampaikan keresahan dari pemikiran Prensky (2001) dalam dunia pendidikan Makalah mereka mempertanyakan klaim utama tentang digital-natives di mana pemikiran mereka mendebat karena istilah ini telah menimbulkan "kepanikan moral" sehingga mereka memberikan pemikirannya dalam bentuk akademis dengan pendekatan yang lebih terukur sehingga diperlukan penelitian lebih lanjut tentang penggunaan istilah 'digital-natives' dan implikasinya terhadap pendidikan. Mereka berpendapat bahwa adanya seruan untuk melakukan perubahan besar seiring dengan hadirnya teknologi dalam dunia pendidikan. Anggapan mereka bahwa masih kurangnya penyelidikan secara kritis, kurangnya teori dan tidak memiliki dasar empiris yang kuat. Kondisi ini menimbulkan perlunya ketersegeraan untuk penelitian ini diinformasikan secara teoritis (Bennett, Maton, \&; Kervin, 2008).

Hadirnya perdebatan terhadap pemikiran Prensky (2001) ini membuat peneliti melakukan telaah pustaka terkait "Digital-Natives" mulai dari awal istilah ini hadir hingga tahun 2020. Didapati penelitian yang muncul adalah sebagai berikut :

Tabel 2. Telaah Pustaka

\begin{tabular}{|c|l|l|l|}
\hline $\begin{array}{c}\text { Publishing } \\
\text { Year }\end{array}$ & \multicolumn{1}{|c|}{ Title of Article } & $\begin{array}{c}\text { Author(s) } \\
\text { Name and } \\
\text { Years of } \\
\text { Writing }\end{array}$ & \multicolumn{1}{|c|}{ Journal / Article } \\
\hline $\mathbf{2 0 0 1}$ & Digital-native , Digital Immigrant (part 1) & $\begin{array}{l}\text { Prensky, } \\
2001 \mathrm{~b}\end{array}$ & $\begin{array}{l}\text { The Strategic Planning for } \\
\text { education Research / } \\
\text { Horizon }\end{array}$ \\
\cline { 2 - 4 } & Digital-native, Digital Immigrant (Part 2) & $\begin{array}{l}\text { Prensky, } \\
\text { 2001a }\end{array}$ & $\begin{array}{l}\text { The Strategic Planning for } \\
\text { education Research / } \\
\text { Horizon }\end{array}$ \\
\hline \multirow{2}{*2008}{} & $\begin{array}{l}\text { The 'digital-natives' debate: A critical review } \\
\text { of the evidence }\end{array}$ & $\begin{array}{l}\text { Bennett, } \\
\text { Maton, \& } \\
\text { Kervin, 2008 }\end{array}$ & $\begin{array}{l}\text { British Journal of } \\
\text { Educational Technology }\end{array}$ \\
\hline & Digital-natives, dropouts and refugees: & McCarthy \& & Management, Policy \& \\
\hline
\end{tabular}




\begin{tabular}{|c|c|c|c|}
\hline & Educational challenges for innovative cities & Vickers, 2008 & Practice \\
\hline 2010 & Digital-natives: Where is the evidence & $\begin{array}{l}\text { Helsper \& } \\
\text { Eynon, } 2010\end{array}$ & $\begin{array}{l}\text { British educational } \\
\text { Research Journal }\end{array}$ \\
\hline \multirow[t]{2}{*}{2011} & Discourse about Digital-native & $\begin{array}{l}\text { Thornham \& } \\
\text { McFarlane, } \\
2011\end{array}$ & $\begin{array}{l}\text { Information } \\
\text { Communication and } \\
\text { Society }\end{array}$ \\
\hline & $\begin{array}{l}\text { Deconstructing Digital-natives: Young People, } \\
\text { Technology and the New Literacies }\end{array}$ & $\begin{array}{l}\text { Thomas, } \\
2011\end{array}$ & $\begin{array}{l}\text { Journal of Children and } \\
\text { Media }\end{array}$ \\
\hline 2012 & $\begin{array}{l}\text { Educators Engage Digital-natives and Learn } \\
\text { from Their Experiences with Technology }\end{array}$ & $\begin{array}{l}\text { Downes \& } \\
\text { Bishop, } 2012\end{array}$ & Middle School Journal \\
\hline 2013 & $\begin{array}{l}\text { Teaching Mapping for Digital-natives: New } \\
\text { Pedagogical Ideas for Undergraduate } \\
\text { Cartography Education }\end{array}$ & $\begin{array}{l}\text { Harvey \& } \\
\text { Kotting, } 2011\end{array}$ & $\begin{array}{l}\text { Cartography and } \\
\text { Geographic Information } \\
\text { Science }\end{array}$ \\
\hline 2014 & $\begin{array}{l}\text { Digital-natives or Digital Immigrants? The } \\
\text { Impact of User Characteristics on Online Trust }\end{array}$ & $\begin{array}{l}\text { Hoffmann, } \\
\text { Lutz, \& } \\
\text { Meckel, } 2014\end{array}$ & $\begin{array}{l}\text { Journal of Management } \\
\text { Information Systems }\end{array}$ \\
\hline \multirow{5}{*}{2015} & & & \\
\hline & $\begin{array}{l}\text { Do digital-natives differ by computer self- } \\
\text { efficacy and experience? An empirical study }\end{array}$ & Teo, 2015 & $\begin{array}{l}\text { Interactive Learning } \\
\text { Environments }\end{array}$ \\
\hline & $\begin{array}{l}\text { Deconstructing the Metanarrative of the } 21 \mathrm{st} \\
\text { Century Skills Movement }\end{array}$ & $\begin{array}{l}\text { Greenlaw, } \\
2015\end{array}$ & $\begin{array}{l}\text { Educational Philosophy and } \\
\text { Theory }\end{array}$ \\
\hline & $\begin{array}{l}\text { The effects of generational differences on use } \\
\text { continuance of Twitter: an investigation of } \\
\text { digital-natives and digital immigrants }\end{array}$ & $\begin{array}{l}\text { Metallo \& } \\
\text { Agrifoglio, } \\
2015\end{array}$ & $\begin{array}{l}\text { Behaviour and Information } \\
\text { Technology }\end{array}$ \\
\hline & $\begin{array}{l}\text { Digital skills and social media use: how } \\
\text { Internet skills are related to different types of } \\
\text { Facebook use among 'digital-natives' }\end{array}$ & Correa, 2015 & $\begin{array}{l}\text { Information } \\
\text { Communication and } \\
\text { Society }\end{array}$ \\
\hline 2016 & $\begin{array}{l}\text { A Piece of Qualitative Study About Digital- } \\
\text { natives }\end{array}$ & $\begin{array}{l}\text { Uygarer, } \\
\text { Uzunboylu, } \\
\text { \& Ozdamli, } \\
2016\end{array}$ & Anthropologist \\
\hline \multirow[t]{3}{*}{2018} & $\begin{array}{l}\text { Educating digital-natives for the future: } \\
\text { accounting educators' evaluation of the } \\
\text { accounting curriculum }\end{array}$ & $\begin{array}{l}\text { Al-Htaybat, } \\
\text { von Alberti- } \\
\text { Alhtaybat, \& } \\
\text { Alhatabat, } \\
2018\end{array}$ & Accounting Education \\
\hline & Teaching Digital Divide & Warf, 2018 & Journal of Geography \\
\hline & $\begin{array}{l}\text { Students' perceptions of the educational usage } \\
\text { of a Facebook group }\end{array}$ & Chen, 2018 & $\begin{array}{l}\text { Journal of Teaching in } \\
\text { Travel and Tourism }\end{array}$ \\
\hline \multirow[t]{4}{*}{2019} & $\begin{array}{l}\text { How technology has shaped university } \\
\text { students' perceptions and expectations around } \\
\text { higher education: an exploratory study of the } \\
\text { United Arab Emirates }\end{array}$ & Ashour, 2019 & Studies in Higher Education \\
\hline & $\begin{array}{l}\text { From Digital-native to Digital apprentice. A } \\
\text { case study of the transmedia skill and informal } \\
\text { learning strategies of adolescents in Spain }\end{array}$ & $\begin{array}{l}\text { Masanet, } \\
\text { Guerrero- } \\
\text { Pico, \& } \\
\text { Establés, } \\
2019\end{array}$ & $\begin{array}{l}\text { Learning, Media and } \\
\text { Technology }\end{array}$ \\
\hline & the Digital-native Assessment Scale (DNAS) & $\begin{array}{l}\text { Huang, Teo, } \\
\text { \& He, } 2019\end{array}$ & $\begin{array}{l}\text { Interactive Learning } \\
\text { Environments }\end{array}$ \\
\hline & Engaging Student as Digital Citizen & $\begin{array}{l}\text { Blaj-Ward \& } \\
\text { Winter, } 2019\end{array}$ & $\begin{array}{l}\text { Higher Education Research } \\
\text { and Development }\end{array}$ \\
\hline 2020 & $\begin{array}{l}\text { Curating the use of digital media in higher } \\
\text { education: a case study }\end{array}$ & $\begin{array}{l}\text { (Herrmann, } \\
\text { Lindvig, \& } \\
\text { Aagaard, } \\
\text { 2020) }\end{array}$ & $\begin{array}{l}\text { Journal of Further and } \\
\text { Higher Education }\end{array}$ \\
\hline
\end{tabular}

Sumber : Olahan penulis, 2021 
Kritik masih berlanjut hingga tahun 2011 di mana perlu rekonstruksi tentang penggunaan wacana "digital native" yang terkait hadirnya kaum muda, teknologi dan literasi baru dalam dunia pendidikan. Penggunaan istilah digital-native memang sah-sah saja namun tidak bisa disetarakan bagi setiap negara bagian. Pernyataan ini didukung dengan sebuah essai tentang generasi mobile oyaubibunka ("budaya ibu jari") di Jepang dari Takashi (2011) menunjukkan bahwa kaum muda di Jepang memiliki waktu yang banyak dalam budaya kolaboratif dan co-creation

Ruang sosial baru diciptakan sehingga kondisi ini menunjukkan penolakan akan sekedar hadirnya ruang kebebasan yang menciptakan ketegangan antara tradisionalisasi dan modernitas di Jepang (Thomas, 2011). Hal ini menujukan bahwa Interaksi sosial bersifat formatif dalam perkembangan struktur kognitif. Pengguna pelajari apa yang perlu dipertimbangkan dan bagaimana mengevaluasi isyarat ketika merenungkan transaksi online berdasarkan pengalaman pembelajaran bersama Dengan kata lain, pengalaman belajar bersama mengarah pada struktur kognitif umum yang menjadi dasar pertimbangan untuk saling mempercayai (Hoffmann et al., 2014).

Peneliti mengkaji bahwa identitas personal digital-native yang notabene hasil pemikiran dari wilayah barat belum tentu dapat digunakan sepenuhnya pemikiran timur diluar keterkaitannya dengan sekedar istilah. Penggunaan istilah digital-native memang dapat digunakan secara global namun secara identitas perlu dicermati lebih jauh secara per wilayah. Hal ini seperti yang dicontohkan oleh penelitian di Jepang dengan budaya kolektif nya tentunya tidak bisa disamakan dengan budaya individualnya.

\section{Pemberlakukan Identitas Antar Generasi}

Enacted-Identity merupakan cara memberlakukan identitas personal melalui ekspresi konsep diri. Hal ini berkaitan dengan bagaimana suatu generasi mengomunikasikan identitasnya kepada orang lain (Gheorghiu \&; Stephens, 2016; Hecht, 1984, 1998; Jaspal, 2015; McCune, 2019; Ramsey et al., 2019). Prensky (2001) menuliskan dalam artikelnya "Our students have changed radically Todays students are no longer the people our educational system was designed to teach". Kehadiran generasi digital dianggap sebagai perubahan secara radikal maka sistem pendidikan yang sudah dirancang sebelumnya dianggap tidak cocok lagi digunakan. Kondisi ini menuntut dosen untuk menegosiasikan identitas nya sesuai dengan perkembangan jaman. Identitas personal yang telah dinegosiasikan perlu diberlakukan dalam aktivitas dalam dunia pendidikan. Kondisi negosiasi identitas personal dan pemberlakuannya dapat dilihat dalam tabel 3 berikut ini:

Tabel 3. Perbedaan Digital-Native dan Digital Immigrant

\begin{tabular}{|l|l|}
\hline \multicolumn{2}{|c|}{ Proses Pencarian Informasi } \\
\hline $\begin{array}{l}\text { Generasi ini belajar dari dosen atau guru mereka } \\
\text { yang juga kelompok immigrant sebelumnya. }\end{array}$ & $\begin{array}{l}\text { Kelompok ini tumbuh berkembang bersama } \\
\text { teknologi sehingga disebut sebagai "Native Speakers } \\
\text { of digital language of computer, video games and } \\
\text { internet" }\end{array}$ \\
\hline $\begin{array}{l}\text { Perlu adanya sosialisasi kembali terhadap informasi } \\
\text { yang didapatkan secara face to face atau langsung }\end{array}$ & $\begin{array}{l}\text { Kelompok ini dianggap mampu menerima informasi } \\
\text { pembelajaran melalui internet, komputer, video } \\
\text { amusement, musik , ponsel dan perangkat digital } \\
\text { lainnya. }\end{array}$ \\
\hline
\end{tabular}




\section{Proses Konfirmasi}

Kelompok generasi yang membutuhkan penegasan Generasi yang tidak membutuhkan penegasan kembali pada sesuatu yang dikirim dengan internet kembali karena mereka dekat dengan perangkat seperti "apakah kamu sudah membaca email saya?" terkini.

\section{Proses Belajar Mengajar}

Proses belajar dilakukan secara step by step.

Generasi ini tidak percaya bahwa siswa mereka dapat belajar dengan sukses saat menonton TV atau mendengarkan musik.

Generasi ini cenderung menyalahkan apabila mahasiswa membuka laptop ketika berada di dalam kelas dan dianggap tidak memperhatikan ketika menjelaskan.

Sumber: (Prensky, 2001)

Pengalaman generasi dosen dan mahassiwa menghadirkan konsep pemikiran yang berbeda. Kondisi ini membentuk identitas yang berbeda juga. Proses pemberlakukan identitas ditunjukan melalui hubungan relasional (relational identity) dan kehidupan berkomunal (communal). Identitas relasional adalah konsep yang datang atau didapatkan dari orang lain atau dikonseptualisasikan dalam suatu hubungan. Identitas komunal dibentuk oleh keanggotaan kelompok dan dan harapan yang didasarkan pada diri kolektif yang lebih besar. Identitas komunal dibangun secara sosial di tingkat kelompok, hasil dari asosiasi dalam kelompok kolektif, dan mencerminkan cara di mana wacana sosial dan budaya (Gheorghiu \& Stephens, 2016; Hecht, 1984, 1998; Jaspal, 2015; McCune, 2019; Ramsey et al., 2019).

\section{Identitas Relasional dan Komunal}

Kehidupan relasional dan komunal generasi digital-natives tidak dapat dipisahkan dari teknologi. Kajian dari Jurnal Innovation Management, Policy \&; Practice melaporkan bahwa adanya tantangan bagi dunia pendidikan dalam menginovasikan sebuah kota hal ini akan sangat bergantung pada sistem pendidikan yang mampu menciptakan karakter manusia dengan skill problem solving dan keahlian yang mampu menjawab tantangan (challenge) dan perubahan (change) secara berkelanjutan. Perubahan tersebut akan mendukung pembentukan identitas personal dari generasi digital-natives yang akan diberlakukan oleh mereka dalam kehidupan berelasi dan berkomunal. Kondisi ini akan menjadi tren seiring dengan meningkatnya teknologi interaktif dan cara teknologi tersebut digunakan oleh penutur asli teknologi untuk mengeksplorasi identitas, kemampuan, dan minat mereka (McCarthy \&; Vickers, 2008).

McCarthy \&; Vickers (2008) menjelaskan bahwa untuk mendukung pengajaran dibutuhkan pendekatan service learning. Pendekatan ini menunjukkan adanya hubungan pengetahuan akademis dengan layanan masyarakat melalui sebuah refleksi. Kondisi ini akan mendorong siswa untuk terlibat aktif dalam memberikan layanan pada masyarakat. mahasiswa akan mampu menerapkan apa yang mereka ketahui sekaligus merefleksikan apa yang telah mereka alami. Peran sentral dosen dalam membimbing dan memfasilitasi pembelajaran mahasiswa membuat tuntutan baru pada mereka tentang bagaimana materi kurikulum terintegrasi dengan layanan masyarakat. Meskipun demikian, kelas tetap menjadi 
tugas dan tanggung jawab dosen untuk mengatur, merencanakan, dan menilai proses pembelajaran tersebut.

Prenksy mengeluarkan buku yang berjudul Teaching Digital-natives. Terdapat 10 pembahasan mengenai pedagogi di era teknologi baru yang dipaparkan sebagai bekal bagi para pengajar dalam menghadapi siswa dari kelompok digital-natives (Prensky, 2010). Pembahasan mengenai pedagogi dijabarkan sebagai berikut :

\section{Bermitra dengan Pedagogi untuk Lanskap Pendidikan Baru}

Mendorong dosen untuk tidak berpikir bahwa penyampaian bahan ajar hanya untuk menyelesaikan perkuliahan. Tujuan pemberian materi adalah untuk membuka wawasan siswa sebagai ramalan beberapa tahun ke depan. Dosen tidak lagi memandang mahasiswa sebagai murid, melainkan partner dalam kegiatan akademik. Pengajaran dalam bentuk pengajaran langsung dinilai sudah tidak efektif lagi. Tugas seorang dosen tidak hanya mengajar, berbicara dan menjelaskan. Pekerjaan rumah siswa lebih dari sekadar mencatat, membaca teks, dan menghafal apa yang telah mereka pelajari.

Pekerjaan dosen bukanlah sebatas penyampaian materi untuk didengarkan namun memastikan mahasiswa memahami melalui tindakan. Siswa di era digital dapat melihat dan menghargai gurunya yang dianggap kreatif, sinergis, dan mampu menghargai pendapatnya sendiri. Siswa saat ini berkomunikasi dengan perangkat digital mereka. Kondisi ini membuat mereka berharap pada dosen untuk membantu mereka dalam menjawab kebutuhan pertanyaan mereka. Mahasiswa menganggap dosen sebagai fasilitator untuk membatu mereka dalam mengembangkan passion mereka. Mereka ingin diarahkan untuk lebih maju dengan tersedianya teknologi.

Mahasiswa generasi digital dapat dianggap sebagai partner dalam melakukan riset dan menemukan informasi terkini. Dosen dapat melakukan hal ini melalui sistem partnering. Mahasiswa generasi ini akan menghargai dosen nya ketika mampu menjawab keresahan mereka melalui pertanyaan yang mereka ajukan. Mereka lebih senang mendengar penjelasan disertai dengan pengalaman dosennya. Ilmu yang teoritis dapat dintegrasikan dengan praktisnya sehingga memberikan motivasi. Mereka lebih senang ketika penyajian presentasi dosen berupa teks dan media pembelajaran guna membantu pemahaman materi.

Dosen dapat menggunakan istilah partnering dalam membangun hubungan relasional dan komunal dengan mahasiswa generasi digital native. Era digital membuat dosen tidak bertugas untuk memberitahu namun bermitra dengan mahasiswa untuk menjawab pertanyaan tentang permasalahan mata kuliah. Konsep partnering akan memberikan tanggung jawab pada mahasiswa untuk mencari, membuat hipotesis, menemukan jawaban dan membuat prestasi. Tugas dosen adalah memeriksa apa yang mereka kerjakan melalui konteks, ketelitian dan kualitas pekerjaan mahasiswa mereka (Prensky, 2010).

\section{Beralih ke Pedagogi Kemitraan}

Mahasiswa generasi digital pada dasarnya akrab dengan penggunaan teknologi. Bukanlah hal yang sulit bagi mereka menemukan informasi yang dibutuhkan. Kelompok ini hanya membutuhkan konfirmasi bahwa sumber informasi yang mereka dapatkan tergolong 
kredible dalam dunia akademik. Konsep partnering dapat menjadi solusi dalam membina hubungan akademik antara dosen dan mahasiswa. Konsep partnering dalam pedagogi bagi dosen dalam membina hubungan dengan mahasiswa adalah sebagai berikut:

Tabel 4 Konsep Partnering dalam Pedagogi Students' Role Lecturer Roles

\begin{tabular}{|ll|}
\hline \multicolumn{1}{|c|}{ Students' Role } & \multicolumn{1}{c|}{ Lecturer Roles } \\
\hline Student as Researcher & Teacher as coach and guide \\
\hline $\begin{array}{l}\text { Student as technology user and } \\
\text { expert }\end{array}$ & $\begin{array}{l}\text { Teacher as Goal setter and } \\
\text { Questioner }\end{array}$ \\
\hline $\begin{array}{l}\text { Student as Thinker and Sense } \\
\text { Maker }\end{array}$ & Teacher as Learning Designer \\
\hline Student as Word changer & Teacher as Context Provider \\
\hline Student as self-teacher & Teacher as Rigor Provider and \\
& Quality Assurer \\
\hline $\begin{array}{l}\text { Student as another job as } \\
\text { journalist, writer, scientist, } \\
\text { engineer and politician }\end{array}$ & \\
\hline
\end{tabular}

Peralihan proses kemitraan dalam belajar akan menjadi pengalaman baru bagi mahasiswa generasi digital-natives. Konsep ini dapat mendukung peremajaan metode pembelajaran dan membangun kemandirian mahasiswa. Konsep ini menumbuhkan hubungan dosen dan mahasiswa menjadi hubungan profesional. Konsep pemerian instruksi sudah tidak cocok lagi diberikan pada mahasiswa generasi digital native karena tidak dapat memenuhi kebutuhan mahasiswa. Sisi positif dari program kemitraan adalah membuat mahasiswa aktif, memiliki tantangan dalam belajar, memotivasi, merasa bahagian dan memberikan perhatian penuh untuk memiliki target nilai diatas rata-rata (Prensky, 2010).

\section{Thinking "People and Passion "rather than "Classes and Content"}

Dosen perlu menyadari adanya beragam minat di dalam setiap kelas sehingga dosen perlu memberikan perhatian terhadap hal ini. Biasanya antusiasme mahasiswa tersembunyi di dalamnya, sehingga dosen menjadi fasilitator untuk mengeksplorasinya. Dosen bisa mengkaitkan passion mahasiswa dalam proses pembelajaran melalui program kemitraan. Dosen bisa saja memberikan studi kasus sesuai dengan minat mahasiswanya. Kondisi tersebut dapat tercipta dan muncul istilah baru dalam dunia pendidikan yaitu passion-based learning. Sudah menjadi tuntutan baru bagi dosen di era digital untuk mencari apa yang menjadi passion mahasiswanya secara perorangan.

Penelitian terdahulu menunjukkan, pada kuarter pertama hanya kurang $10 \%$ dosen yang mengetahui apa passion dari mahasiswanya. Kuarter kedua ditemukan kurang dari $20 \%$ dan kuarter ketiga kurang dari $40 \%$. Hanya 2 orang yang menjawab lebih dari $70 \%$ dan seorang menjawab $90 \%$. Hal ini menunjukkan bahwa kebanyakan dosen menghabiskan energi mereka dengan menempatkan hasrat mereka dalam pengajaran dan tidak terpikir oleh mereka bahwa mahasiswa mereka memiliki passion masing-masing Alasan lain dari tujuan mengenal passion mahasiswa secara individu adalah untuk memberikan instruksi kepada masing-masing mahasiswa dalam mengerjakan tugas atau memberikan tugas yang berbeda pada setiap mahasiswa. 
Meskipun apa yang dipelajari sama namun setiap mahasiswa mampu mengerjakan sesuatu sesuai dengan preferensi, keinginan dan kesukaan pribadi mereka

\section{Being Real (Not Just Relevant)}

Penting bagi seorang dosen untuk melakukan partnering dengan mahasiswanya denagn melakuka komunikasi secara real dan bukan sekedar relevan dengan topik dikelas. Dosen perlu melakukan segala sesuatunya melalui pernyataan seperti:

Pernyatan Relevan:

"Ayo Baca buku Harry Potter ini karena ini berkaitan dengan topik kita hari ini" Pernyataan Real:

Anda dipersilahkan mencari buku yang membuat anda tertarik sehingga buku tersebut menjadi inspirasi untuk mengubah hidup anda.

Istilah "Real" menjadi perspektif baru di dunia pendidikan dan pembelajaran. Seorang dosen dapat mengajar sesuatu yang berguna bagi masa depan kehidupan mahasiswanya. Seorang mahasiswa mampu belajar teknik persuasi (relevant) namun dapatkah mereka mempersuasi seseorang ketika mereka melakukan sesuatu (real).

Seseorang bisa saja belajar komunikasi bisnis (relevant) namun dapatkan mereka berhasil dalam berkomunikasi dalam bisnis mereka (real). Kondisi tersebut mengharuskan para dosen membuat subjek mereka menjadi sesuatu yang "real" hal ini dalam penyampaian pembelajaran bukan hanya sebatas teori (relevant) saja namun mengkomunikasikan teori dalam kalimat real (Prensky, 2010).

\section{Content to Questions, Questions to Skill}

Konsep pembelajaran bermitra akan memberikan peluang bagi dosen dan mahasiswa dari tugas-tugas yang membosankan terutama untuk mempersiapkan bahan kuliah, tugas yang berulang atau memperbaiki bahan kuliah di periode lalu akan sangat membosankan. Pembelajaran kemitraan ini adalah menerjemahkan isi pelajaran kedalam bentuk pertanyaan ketika akan proses belajar mengajar. Hal yang lebih penting dalam kemitraan adalah membuat hubungan secara eksplisit yang didasari dengan keterampilan. Proses pelaksanaanya melaui pengembangan kata kerja yang akan dipelajari dan dipraktikan oleh mahasiswa saat mereka akan menjawab pertanyaan dan mempelajari isi dari materi pembelajaran (Prensky, 2010).

\section{Using Technology in Partnering}

Dosen yang bermitra dengan mahasiswa akan menjadikan teknologi sebagai pendukung dan bukan dasar keterampilan yang harus dikuasai oleh mahasiswa. Sifat dai penggunaan teknologi hanya sebagai alat untuk bekerja. Dosen akan membuat mahasiswa mandiri dalam mengerjakan tugas bersama kelompoknya. Dosen hanya membimbing mahasiswa sampai mahasiswa menemukan jawaban dan menguasai keterampilan yang diperlukan. Mahasiswa membutuhkan alat untuk menemukan dan mempelajari materi. Dosen sebagai mitra dalam belajar harus mengupayakan teknologi digital untuk mendukung mahasiswa belajar secara mandiri. Hal ini akan mendukung digital pedagogy dengan memandu mahasiswa untuk menjawab pertanyaan yang sudah disusun oleh dosen (Prensky, 2010). 


\section{Understanding the Nouns, or Tools}

Kegiatan pembelajaran dengan bermitra dengan mahasiswa akan membutuhkan alat-alat yang dibutuhkan. Alat-alat tersebut harus disusun berdasarkan abjad dan bukan disusun berdasarkan kepentingan. Buatlah daftar dari kata benda yang akan digunakan dan perlu diketahui kata benda akan berubah secara cepat dan perlu diperbaharui

\section{Letting your student Create}

Mahasiswa di era digital sangat bersemangat dalam membuat sesuatu, tetapi masih ada sedikit peluang untuk mencapai tujuan ini. Alasan siswa bersemangat untuk menciptakan hal-hal baru adalah karena penguasaan teknologi. Mahasiswa membuat banyak hal di luar kampus, dan hanya sedikit orang yang melakukannya dalam proses pembelajaran. Peran dosen sebagai partner adalah memberikan kesempatan kepada mahasiswa dengan membantu dan mendorong mahasiswa untuk berkreasi sebanyakbanyaknya dan menjadikannya pembelajaran formal.

\section{Continuously Improving through sharing and Practice}

Dosen dengan konsep kemitraan dengan mahasiswa mengalami peningkatan keterampilan dalam hal pembinaan (coaching), pengarahan (guiding), penetapan tujuan (goal setting), pertanyaan (questioning), perancangan (designing). Keterampilan dosen dengan sistem kemitraan akan mengalami peningkatan secara terintegrasi dan saling menguatkan. Di samping itu, pembelajaran kemitraan akan lebih cepat dan menjadi lebih mudah. Peningkatan kemitraan antara dosen dan mahasiswa harus saling mendukung dan mengalami peningkatan masing-masing. Mahasiswa dapat belajar mandiri dengan dosen sebagai pembina nya Mahasiswa harus dapat menjadi lebih baik dalam hal mengambil inisiatif, menjawab pertanyaan yang sudah di desain oleh dosen mereka dengan memahami panduan dan meningkatkan keterampilan diri dengan alat yang tersedia.

Penting bagi dosen dan mahasiswa bahwa berlatih secara individual tidaklah menjadikan pengajaran sempurna sehingga mahasiswa butuh praktik untuk mengembangkan kemampuannya dengan memperbanyak latihan Penting bagi dosen yang bermitra dengan mahasiswa memulai pembelajarannya untuk memperkenalkan berbagai kondisi seperti naik atau turunnya suatu keadaan yang tidak terhindarkan, mencoba hal-hal baru, mengerjakan segala sesuatunya dengan tenang, selalu melakukan peninjauan yang terjadi selama proses belajar dan memiliki semangat untuk bekerja dalam rangka peningkatan diri.

\section{Assessment in the partnering Pedagogy}

Pembelajaran mitra antara dosen dan mahasiswa tentunya harus ada penilaian. Kebanyakan penilaian digunakan untuk menentukan peringkat individu yang didasari skor rata-rata, skor lintas kelas dan kelompok sosial. Pemberian skor penilaian dapat dilakukan melalui dua cara yaitu:

\section{a) Penilaian sumatif}


Penilaian jenis ini merupakan penilaian tunggal atau skor berdasarkan tes tanpa umpan balik. Penilaian ini yang biasa digunakan oleh dosen untuk melihat peringkat dan perbandingan.

\section{b) Penilaian formatif}

Penilaian jenis ini adalah penilaian dengan umpan balik yang bisanya dilakukan dengan cara membuat makalah mengukur kedisiplinan seperti berapa kali mahasiswa terlambat dalam kinerjanya, penciptaan suatu pekerjaan atau tugas dan keputusan yang dibuat mahasiswa. Penilaian hanya benar-benar formatif jika umpan balik benar-benar dibaca, dipikirkan, dan ditindaklanjuti.

Keberadaan digital-native menjadi tantangan sendiri bagi penyelenggara pendidikan oleh karena itu perlunya mendekonstruksi pemahaman mengenai digital-native ini sendiri sebagai generasi yang hadir dalam dunia pendidikan (Thomas, 2011). Kondisi kehadiran generasi ini menjadi tantangan sendiri bagi penyelenggara pendidikan untuk memulai trial and error dalam memproses pembelajaran melalui dengan mengutamakan grafis dibandingkan teks mereka (Deubel, 2006; Glasser, 1998; Prensky, 2001 dalam Downes \& Bishop, 2012) serta menghubungkan pada dunia professional sebagai bentuk relevasi nya. Ibarat kata ini memberikan pernyataan pada mereka mengenai relevansi mata kuliah dan kegunaanya

Downes \& Bishop (2012) menjelaskan bahwa generasi digital memiliki pemikiran kritis, lebih mengutamakan kolaborasi dalam mengerjakan tugas pembelajaran dan kreativitas yang sesuai dengan abad 21 (Partnership for 21st Century Skills, 2009 dalam Downes \& Bishop, 2012). Hal ini sangat kontras dengan pemikiran sebelumnya di mana sekolah identik dengan keunggulan buku teks dan penekanan nilai pada test. Tidak dapat dipungkiri bahwa hadirnya generasi digital dengan identitasnya mengalami ketidaksesuaian dengan bentuk literasi yang diajarkan di Lembaga pendidikan yang lebih menekankan pada pelaksanaan pendidikan secara kolaboratif. Meskipun banyak siswa setiap hari bergantung pada teknologi yang menghubungkan mereka dengan cepat ke informasi apa pun yang mungkin mereka perlu kan, sebagian besar sekolah tidak mengizinkan penggunaan alat-alat ini dalam kelas (Bushweller, 2006 dalam Downes \& Bishop, 2012).

Bruce dan Levin (1997) menawarkan tipologi cara di mana teknologi dapat mendukung pembelajaran yang tetap relevan dan bermanfaat untuk sekolah saat ini. Mereka menyarankan teknologi ruang kelas dapat diterapkan dengan empat fokus berbeda: (1) Penelitian (2) komunikasi, (3) konstruksi, dan (4) ekspresi. Sementara siswa di sekolah menghargai efisiensi penggunaan teknologi untuk inkuiri dan komunikasi, waktu yang mereka identifikasi sebagai keterlibatan paling sering terjadi ketika mereka menerapkan teknologi untuk konstruksi dan ekspresi saja (Downes \& Bishop, 2012).

Semakin berkembang dan menarik minat para peneliti hingga muncullah konsep pedagogi yang dapat digunakan untuk pembelajaran dengan digital-native ini. Hadirnya kelompok digital-natives telah membawa perubahan pada konsep-konsep pembelajaran. Sebuah jJurnal Internasional menjelaskan ada 7 tahapan sebagai proses harian dalam pembelajaran aktif di kelas seperti pada gambar 1 dibawah ini (Harvey \& Kotting, 2011). Proses diawali dengan melakukan review dari pertemuan sebelumnya dengan memberikan 
umpan balik kepada mahasiswa dan proses ini dipimpin oleh dosen didalam kelas. Dosen melanjutkannya dengan memperkenalkan topik baru dan menciptakan grup diskusi dan pada tahap ini dosen masih memimpin jalannya kelas.

Mahasiswa dan dosen menjalin interaksi dengan kebaruan topik tersebut dan menanyakan umpan balik dari mahasiswa. Dosen membangun diskusi dengan mahasiswa dengan mengajukan pertanyaan pada mahasiswa. Setelah selesai berdiskusi, dosen melanjutkan aksinya dengan memperkenalkan suatu masalah dengan penerapannya. Dosen boleh membagikan tugas untuk dipecahkan secara individual atau berkelompok dan diakhiri dengan penyelesaian masalah bersama kelompok (Harvey \& Kotting, 2011)

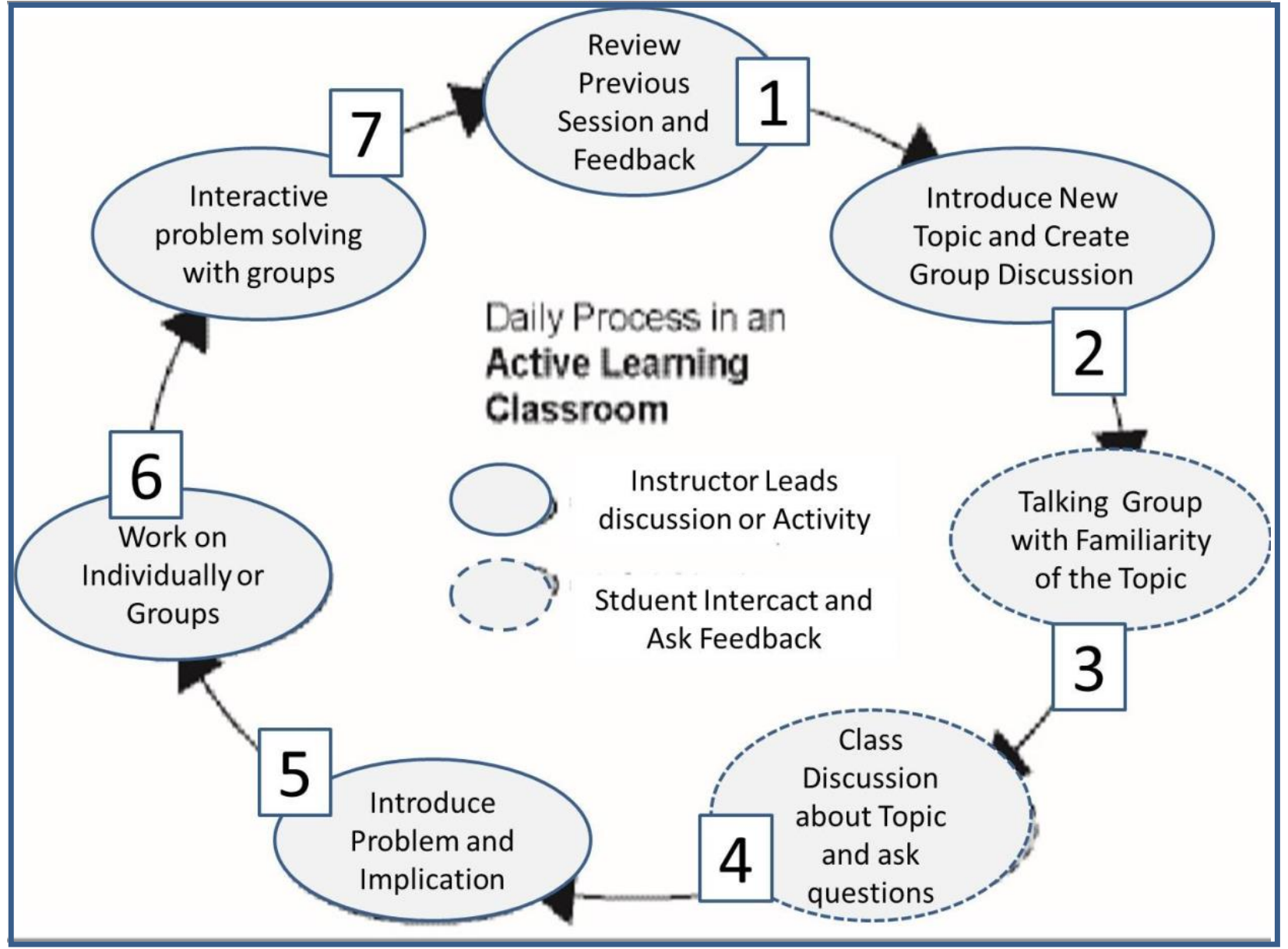

Gambar 1. Daily Process in a Learning Classroom (Harvey \& Kotting, 2011)

Selain proses dalam pembelajaran di kelas, penelitian juga berkembang secara pergerakan keahlian (Skill Movement) di mana lima keahlian yang harus diperhatikan ketika mengajar di abad 21 (Greenlaw, 2015) adalah sebagai berikut:

\section{a. Direct Instruction versus Interactive Exchange}

Teori pembelajaran dan mengajar dari Marc Prensky menjelaskan perlunya perubahan dalam mengajar yaitu dari cara dengan instruksi langsung (Direct Instruction) menjadi pembelajaran interaktif (Interactive learning). Selain itu dalam kegiatan belajar mengajar di era digital, dosen dan mahasiswa berbagi tanggung jawab dalam membangun pengetahuan dalam kelas. Kondisi ini disebut sebagai 
pendekatan kemitraan “Partnering Approach” di era digital (Prensky, 2010 dalam Greenlaw, 2015).

Perubahan dari direct instruction menjadi interactive exchange ini menjadi strategi yang memiliki nilai yang berpeluang untuk mahasiswa mengkonstruksi pengetahuan mereka sendiri melalui pendekatan pembelajaran yang berbasis masalah (Problem-based) dan project (Project-Based) dengan posisi dosen sebagai pemandu dalam kelas Instruksi langsung memang masih dibutuhkan di pembelajaran abad 21 dan digunakan ketika dosen ingin membantu siswa menemukan pola dan mencari makna di tengah banyaknya informasi yang tersedia secara online (Greenlaw, 2015).

Peneliti melihat peran dosen saat ini bukan hanya sekedar menyampaikan materi ketika melakukan direct instruction namun keberadaan teknologi telah membuat mahasiswa mampu mengakses teknologi sehingga dosen perlu menjadi fasilitator dalam mengarahkan mahasiswa agar tidak tersesat memahami materi di tengah mudahnya akses pencarian informasi. Hal ini terkait tuntutan yang berkenaan dengan identitas personal baru di era digital.

\section{b. Content versus Process}

Hadirnya ruang sibernetika telah merubah ruang interaksi antara dosen dan mahasiswa dan disebut sebagai kolektivisme (Siemens, 2004 dalam Greenlaw, 2015). pendidikan formal dapat terjadi dalam berbagai cara seperti melalui komunitas praktisi, jemaring pribadi dan melalui studi kasus yang sesuai dengan pekerjaan. Mahasiswa saat ini belajar kolaboratif secara online meskipun saat ini proses tersebut dianggap tidak resmi dan kompleks. Konten dibuat kekinian dan dapat di akses dari mana saja sehingga hal ini berbeda dengan sistem pembelajaran 10 atau 20 tahun lalu (Levy, 1999 ; Siemens, 2004 dalam Greenlaw, 2015).

\section{c. One-size-fits-all versus Personalized}

Dunia pendidikan kini mendapat tututan baru dengan hadirnya generasi digital yang terus bertambah. Model one -size-fit - all atau model satu ukuran untuk semua dalam dunia pendidikan tidak dapat dipergunakan lagi dalam dunia pendidikan. Berkembangnya mahasiswa net generation ini memiliki pandangan baru yaitu kebutuhan akan kebebasan berekspresi di mana hal ini menjadi salah satu dasar pembentukan identitas bagi generasi tersebut dalam membentuk pandangan pribadi mahasiswa generasi ini berharap kebutuhan akan komunikasi dan informasi dapat dipenuhi oleh dosen mereka (Trilling dan Fadel, 2009 dalam Greenlaw, 2015).

\section{d. Classroom versus Global Community}

Salah satu yang menjadi peningkatan keterampilan pada abad kedua puluh satu ini adalah kemampuan dosen dalam meningkatkan komunikasi antar budaya bagi mahasiswa dengan membangun kesadaran global dengan menghubungkan antar mahasiswa ke seluruh dunia melalui ruang kelas. Internet dipercaya dapat memenuhi tuntutan dan memberikan peluang yang baik di mana tidak ada penyekat antara dinding mahasiswa di suatu Negara dengan Negara lain sehingga ini menjadi perhatian bagi dosen-dosen di negara maju . Hal ini dilakukan untuk mendorong kompetensi secara teknologi bagi mahasiswa untuk mampu berkompetisi dalam 
perekonomian global (Greenlaw, 2005a, 2005b, 2001, 2000; Greenlaw, Desjardins, \& Robertson, 2009; Greenlaw \& Whittaker, 19972009 dalam Greenlaw, 2015).

\section{e. Learning for School versus Learning for Life}

Poin terakhir ini merupakan sebuah perselisihan mengenai pembelajaran. Pertama, masih dipertanyakan dari pembelajaran saat ini dapat mengembangkan moral, pembentukan identitas budaya, kecerdasan kolektif, hypertext dan hubungan virtual dapat menggantikan buku teks tradisional secara tatap muka. Kehadiran dosendosen secara tradisional telah dipercaya untuk membantu mahasiswanya dalam hal bertahan hidup di kampus dari pada memberikan pelajaran untuk seumur hidup. Dosen dapat menerapkannya dalam kegiatan belajar mengajar (Greenlaw, 2015).

Lembaga pendidikan tinggi memiliki peranan penting dalam mempersiapkan mahasiswa untuk mampu bersaing dengan kompleksitas dunia kerja dengan teknologi yang semakin berkembang. Selama proses belajar, seorang dosen perlu memahami mahasiswa terkini dimana mereka menggunakan teknologi baik di dalam maupun luar kelas. Mahasiswa tidak sepenuhnya bergantung pada teknologi karena pembelajaran secara konvensional masih berlaku dan dosen masih sangat dibutuhkan khususnya untuk memberikan materi secara pendekatan formal namun perlu dipadukan dengan teknologi baru (Ashour, 2019) Lingkungan belajar informal menjadi ruang penting untuk menggunakan dan mengembangkan literasi digital (Masanet et al., 2019)

Kondisi dosen saat ini bukan hanya dari kelompok digital immigrant saja namun digital-native periode awal (lahir pada tahun 1980) pun sudah memasuki dunia pendidikan dan berprofesi sebagai dosen. Kelompok dosen digital-native awal juga mendapatkan pengaruh dari generasi sebelumnya. Dosen telah mengubah cara mereka berpikir dan memproses informasi dengan membawa teknologi ke ruang kelas untuk pengajaran dan pembelajaran, membuat catatan, meningkatkan motivasi siswa, dan memfasilitasi keterlibatan mereka (Raghunath, Anker, \& Nortcliffe, 2018 dalam Huang et al., 2019). Dosen perlu melalakuakan engaging dengan mahasiswa dari kelompok digital (Digital Citizen) untuk lancaranya hubungan dengan mereka (Blaj-Ward \& Winter, 2019).

Dalam pembelajaran di dunia pendidikan, mahasiswa perlu dilengkapi dengan beberapa keterampilan yaitu pertama, keterampilan digital baik itu secara teknis untuk untuk menyelesaikan tugas praktis, Kedua keterampilan manajemen untuk menemukan, memilih, dan mengatur informasi, ketiga keterampilan kolaborasi untuk mengembangkan jaringan sosial dan bekerja dalam tim (Van Laar et al. 2017 dalam Herrmann, Lindvig, \& Aagaard, 2020). Wacana 'pro-teknologi' seperti membatasi akses mahasiswa ke laptop dapat memicu reaksi keras terhadap pendidik. Tindakan ini tidak hanya dapat ditafsirkan sebagai langkah reaksioner yang dilakukan oleh imigran digital yang gagal memahami pentingnya teknologi digital, namun juga tampaknya tidak bertanggung jawab untuk menghalangi perolehan keterampilan siswa abad ke-21 (Herrmann et al., 2020). 


\section{SIMPULAN}

Dosen perlu menyadari adanya kehadiran mahasiswa generasi baru berikut identitasnya hadir di dunia pendidikan tinggi. Perbedaan identitas antara dosen dan mahasiswa merupakan kesenjangan yang harus dicari solusinya. Solusi dari kesenjangan tersebut dapat disolusikan melalui komunikasi, mengingat identitas merupakan produk komunikasi. Dosen perlu memahami kehadiran generasi baru secara personal, enactment, relational dan communal dalam konteks komunikasi pendidikan. Pentingnya memahami latar belakang geodemografi dari generasi digital-natives di Indonesia karena keberagaman yang ada. Pengalaman hidup masing-masing individu akan dibawa dan melebur melalui negosiasi diri. Kondisi ini akan dilihat dosen sebagai satu identitas yaitu mahasiswa. Pemahaman akan digital-natives memiliki peluang untuk diteliti secara perwilayahan sehingga dapat dilihat benang merah mengenai identitas generasi digital-natives. Dengan mengenal generasi digitalnatives akan membantu dosen menemukan strategi dalam komunikasi pembelajaran untuk mengatasi kesenjangan.

\section{UCAPAN TERIMA KASIH}

Terima kasih kepada Allah SWT ,Rasullulah SAW dan para sahabatnya, orang tua dan istri atas doa dan dukungannya untuk tetap berkarya memberikan sumbangsih berupa ilmu pengetahuan. Jazakumullah kharian katsira buat semua pihak di Jurnal Avant Garde yang memberikan kesempatan. Semoga artikel saya bermanfaat bagi umat dan penggiat komunikasi pendidikan. Buat para reviewer, terima kasih atas kesediaan untuk memeriksa artikel ini agar lebih baik untuk dibaca. Semoga artikel ini dapat bermanfaat bagi para dosen yang menghadapi mahasiswa generasi digital sehingga menjadi referensi untuk mengembangkan dalam hal komunikasi pembelajaran melalui identitas mahasiswa generasi digital.

\section{DAFTAR PUSTAKA}

Al-Htaybat, K., von Alberti-Alhtaybat, L., \& Alhatabat, Z. (2018). Educating digital natives for the future: accounting educators' evaluation of the accounting curriculum. Accounting Education, 27(4), 333-357. https://doi.org/10.1080/09639284.2018.1437758

Ashour, S. (2019). How technology has shaped university students' perceptions and expectations around higher education: an exploratory study of the United Arab Emirates. Studies in Higher Education, $0(0), \quad 1-13$. https://doi.org/10.1080/03075079.2019.1617683

Bennett, S., Maton, K., \& Kervin, L. (2008). The "digital natives" debate: A critical review of the evidence. British Journal of Educational Technology, 39(5), 775-786. https://doi.org/10.1111/j.1467-8535.2007.00793.x

Bergquist, G., Soliz, J., Everhart, K., Braithwaite, D. O., \& Kreimer, L. (2019). Investigating Layers of Identity and Identity Gaps in Refugee Resettlement Experiences in the Midwestern United States. Western Journal of Communication, 83(3), 383-402. https://doi.org/10.1080/10570314.2018.1552009

Blaj-Ward, L., \& Winter, K. (2019). Engaging students as digital citizens. Higher Education 
Research and Development, 38(5), 879-892. https://doi.org/10.1080/07294360.2019.1607829

Brooks, C. F., \& Pitts, M. J. (2016). Communication and identity management in a globallyconnected classroom: An online international and intercultural learning experience. Journal of International and Intercultural Communication, 9(1), 52-68. https://doi.org/10.1080/17513057.2016.1120849

Chen, M. M. (2018). Students' perceptions of the educational usage of a Facebook group. Journal of Teaching in Travel and Tourism, 18(4), 332-348. https://doi.org/10.1080/15313220.2018.1434448

Correa, T. (2015). Digital skills and social media use: how Internet skills are related to different types of Facebook use among 'digital natives.' Information Communication and Society, 19(8), 1095-1107. https://doi.org/10.1080/1369118X.2015.1084023

Downes, J. M., \& Bishop, P. (2012). Educators Engage Digital Natives and Learn from Their Experiences with Technology: Integrating Technology Engages Students in Their Learning. Middle School Journal, 43(5), 6-15. https://doi.org/10.1080/00940771.2012.11461824

Ennerberg, E., \& Economou, C. (2020). Migrant teachers and the negotiation of a (new) teaching identity. European Journal of Teacher Education, 00(00), 1-14. https://doi.org/10.1080/02619768.2020.1788536

Gheorghiu, E., \& Stephens, C. S. (2016). Working with "The Others": Immigrant academics' acculturation strategies as determinants of perceptions of conflict at work. Social Science Journal, 53(4), 521-533. https://doi.org/10.1016/j.soscij.2016.08.002

Gravett, Linda; Trockmorton, R. (2007). Bridging the GAP Generations. New Jersey: Career Press.

Greenlaw, J. (2015). Deconstructing the Metanarrative of the 21st Century Skills Movement. Educational Philosophy and Theory, 47(9), 894-903. https://doi.org/10.1080/00131857.2015.1035156

Harvey, F., \& Kotting, J. (2011). Teaching mapping for digital natives: New pedagogical ideas for undergraduate cartography education. Cartography and Geographic Information Science, 38(3), 269-277. https://doi.org/10.1559/1523040638269

Hecht, M. L. (1984). Persuasive efficacy: A study of the relationships among type and degree of change, message strategies, and satisfying communication. Western Journal of Speech Communication, 48(4), 373-389. https://doi.org/10.1080/10570318409374171

Hecht, M. L. (1998). Communicating Prejudice. London and New Delhi: Sage Publication.

Helsper, E. J., \& Eynon, R. (2010). Digital natives: Where is the evidence? British Educational Research Journal, 36(3), 503-520. https://doi.org/10.1080/01411920902989227

Herrmann, K. J., Lindvig, K., \& Aagaard, J. (2020). Curating the use of digital media in higher education: a case study. Journal of Further and Higher Education, 00(00), 1-12. https://doi.org/10.1080/0309877X.2020.1770205

Hoffmann, C. P., Lutz, C., \& Meckel, M. (2014). Digital Natives or Digital Immigrants? The Impact of User Characteristics on Online Trust. Journal of Management Information 
Systems, 31(3), 138-171. https://doi.org/10.1080/07421222.2014.995538

Huang, F., Teo, T., \& He, J. (2019). Digital nativity of university teachers in China: factor structure and measurement invariance of the Digital Native Assessment Scale (DNAS). Interactive Learning Environments, $\quad 0(0), \quad 1-15$. https://doi.org/10.1080/10494820.2019.1570278

Jaspal, R. (2015). Constructing and protecting identity in a diverse higher education context. Perspectives: Policy and Practice in Higher Education, 19(4), 127-134. https://doi.org/10.1080/13603108.2015.1071291

Jung, E., \& Hecht, M. L. (2004). Elaborating the communication theory of identity: Identity gaps and communication outcomes. Communication Quarterly, 52(3), 265-283. https://doi.org/10.1080/01463370409370197

Masanet, M. J., Guerrero-Pico, M., \& Establés, M. J. (2019). From digital native to digital apprentice. A case study of the transmedia skills and informal learning strategies of adolescents in Spain. Learning, Media and Technology, 00(0), 1-14. https://doi.org/10.1080/17439884.2019.1641513

McCarthy, F., \& Vickers, M. (2008). Digital natives, dropouts and refugees: Educational challenges for innovative cities. Innovation: Management, Policy and Practice, 10(2-3), 257-268. https://doi.org/10.5172/impp.453.10.2-3.257

McCune, V. (2019). Academic identities in contemporary higher education: sustaining identities that value teaching. Teaching in Higher Education, 0(0), 1-16. https://doi.org/10.1080/13562517.2019.1632826

Memoriautopis.com. (2020). Marc Prensky Biografi / Marc Prensky Biography. Retrieved December 12, 2020, from Memoria Utopis.com website: https://www.memoriautopis.com/2020/11/marc-prensky-biografi.html\#: :text=Marc

Prensky lahir 15 Maret,Middlebury\%2C dan Harvard Business School.\&text=Kini\%2C Prensky adalah Pendiri dan,Future Education Foundation and Institute.

Metallo, C., \& Agrifoglio, R. (2015). The effects of generational differences on use continuance of Twitter: An investigation of digital natives and digital immigrants. Behaviour and Information Technology, 34(9), 869-881. https://doi.org/10.1080/0144929X.2015.1046928

Prensky, M. (2001a). Digital Immigrants, Digital Natives. On the Horizon, 9(5), 1-6. https://doi.org/10.1108/10748120110424816

Prensky, M. (2010). Teaching Digital Natives. United Kingdom: Corwin Press.

Ramsey, M. C., Knight, R. A., \& Knight, M. L. (2019). Student Identification and Communication Instruction: An Examination of Identity Gaps as Predictors of Communication Satisfaction and Teacher Apprehension. Communication Studies, O(0), 1-13. https://doi.org/10.1080/10510974.2019.1650087

Teo, T. (2015). Do digital natives differ by computer self-efficacy and experience? An empirical study. Interactive Learning Environments, 24(7), 1725-1739. https://doi.org/10.1080/10494820.2015.1041408

Thomas, M. (2011). Deconstructing digital natives: Young people, technology and the new literacies. Journal of Children and Media, 2798(June), 1-220. 
https://doi.org/10.4324/9780203818848

Thornham, H., \& McFarlane, A. (2011). Discourses of the digital native: Use, non-use, and perceptions of use in BBC Blast. Information Communication and Society, 14(2), 258279. https://doi.org/10.1080/1369118X.2010.510199

Uygarer, R., Uzunboylu, H., \& Ozdamli, F. (2016). A piece of qualitative study about digital natives. Anthropologist, 24(2), 623-629. https://doi.org/10.1080/09720073.2016.11892057

Warf, B. (2018). Teaching Digital Divides. Journal of Geography, 118(2), 77-87. https://doi.org/10.1080/00221341.2018.1518990 